\title{
Analysis the Use of Semester Package System to Increase GPA for Scholarship Students at Universitas Terbuka, Indonesia
}

\author{
Sri Yuniati Putri Koes Hardini ${ }^{1}$, Durri Andriani ${ }^{2}$ \\ 1. Department of Math \& Sciences, Universitas Terbuka, Indonesia \\ 2. Department of Education, Universitas Terbuka, Indonesia
}

How to cite this paper: Hardini, S. Y. P. K., \& Andriani D. (2018). Analysis the Use of Semester Package System to Increase GPA for Scholarship Students at Universitas Terbuka, Indonesia. The Educational Review, USA, 2(2), 181-188.

http://dx.doi.org/10.26855/er.2018.02.004

Corresponding author: Sri Yuniati Putri Koes Hardini, Department of Math \& Sciences, Universitas Terbuka, Indonesia.

\begin{abstract}
The aim of the paper was to analyze the use of Semester Packaged System (SPS) in facilitating students to complete their four years with the minimum GPA 2.50 in the first year, 2.75 in the second year to the last year. The study was conducted in Universitas Terbuka (UT). Based on experiences, UT is aware that the GPA requirements are not easy to meet. Students need face-to-face earning facilitation. SPS is devided into four categories, SPS Plus, SPS Full, SPS Semi, and SPS Non-Face to face. This research analyzes GPAs from SPS Plus, SPS Semi, and SPS non-Face to face. Two types of data were used, all students' final scores obtained from the office of UT's Examination Centre and students perception on Face to face implemtation obtained from questionnaires. The 6 locations of samples were chosen purposively from 37 UT's Regional offices that offered scholarship. T-test was employed to examine diffrences between scholarship-students based on the scholarship types and semesters of the students. Results showed that almost in all situasion, students in SPS Plus have significantly higher GPA than other types of scholarship except in one situation. There was no significant differences beetween GPAs of SPS Plus and SPS Semi in the second semester. These results, to some extent, could cause by positive perceptions of SPS Plus students towards face to face services.
\end{abstract}

\section{Keywords}

Face to Face Tutorial, GPA, SPS

\section{Introduction}

During the last five years, Universitas Terbuka (UT) experiences shifting in students age. In the first 25 years of operation, UT had mostly mature-students. This condition is changed where at present UT has around 16\% senior high school graduates in its student population. This shifting is consistent with UT policies to widening opportunities for younger students to enjoy higher education otherwise impossible to afford. Inability to afford higher education is commonly attributed to no universities available in the area, no time to come to classes, and not enough money to pay the fees. UT bridges this demand in higher education level and not enough resources to get it by providing scholarship. The scholarship mostly comes from government-own and private entities as part of their corporate social responsibility (CSR) programs. Notwithstanding, the grantors requires their grantees to follow some rules, such as graduate timely (4 years) and have a minimum GPA score of 2.50 in the first year, 2.75 in the second year, and 3.00 for the third and last year. Students fail to achieve the required scores will automatically be released from the scgolarship scheme. 
Compared with present means of students GPA $(2,19-2,27)$ stated in Annual Report of Universitas Terbuka's Rector (2013), UT have to take several measures to anticipate the scholarship-students' required GPAs. The measures include set high academic standard requirements for elligible candidates and provide proper learning support for accepted students. To be elligible for the scholarship, fresh graduates from high school should have good grade. They have to pass academic selection conducted by UT. For some scholarship scheme, economically-disadvantage is one of the reasons to be accepted. However, this paper limits its analysis on scholarship which exclude economically-disadvantage as one of its terms based on bias which could appear on students' performance cause by poverty. Once students are decided and confirmed as grantees, they have the right to utilize all learning supports provided by the University.

UT support system in the form of tutorial could partially resolve a problem with self-directed learning and efforts to mastering learning materials. One type of learning support is face to face conducted by UT regional office or better known as Regional Office. Face to face are conducted eight times in a semester for a course. During tutorial sessions, students must complete three assignments given at the 3rd, 5th, and 7th sessions (UT, 2016). The assignments have to be finished in class during the tutorial session. In Face to face, students are required to actively participate in the discussions and assignments. Tutors come from reputable institutions and meet the requirements set forth by UT.

In term of scholarship-students, aware of difficulties scholarship-students faced in implementing self-directed learning and possibility to fail in achieving required GPAs, UT provides Semester Package System (SPS). SPS is an approach for one program where its courses in curriculum are divided into eight semester-packaged. Courses are grouped into certain packages because some students find it difficult to decide how many courses they should take in a semester. Some take too many while some others take too little courses. SPS is aimed at facilitating students learning process in accordance to their conditions so that the learning process can be performed optimally and studies can be completed on time. Having this in mind and taking financial consideration of the grantors, UT developed four types SPS namely SPS Plus (face to face tutorial for all registered-courses and training), SPS Full (Face to face tutorial for all registered-courses), SPS Semi (face to face tutorial for half of the registered-courses), and SPS Non-Face to face (No face to face tutorial).

No matter what type of SPS students attending, UT guarantess face to face tutorial quality by ensuring that the Face to face tutorial is planned, implemented, monitored, and evaluated in accordance with according to the established policy of the face to face tutorial. Some considerations related to students learning support is that learning approaches should vary, interactive, student-centered, as well as trying to meet the preferences of different student and designed according to the principles of transparency and open higher distance education (DE) according to the guidelines (Universitas Terbuka, 2012a; Universitas Terbuka, 2013).

Tutorial itself is defined as one of learning supports developed to facilitate students in mastering learning materials. In the tutorial, learning activities are facilitated by tutors who take role as as a facilitator. In tutorial sessions, students discuss four things (Universitas Terbuka, 2016):

- Competence essential or important concepts in a course;

- Problems encountered in the student while studying the modules;

- Issues related to practice/practicum; and

- Issues relating to the application of science in everyday life.

SPS programs for scholarship students has been implemented for four semesters. It is time to analyze its effectiveness by comparing GPAs of students in different types of SPS. Analysis in this paper will be limited for scholarship-students in three SPS programs, namely SPS Plus, SPS Semi, and SPS Non-Face to face. Scholarship-students' perceptions of the implementation of the Face to face is also analyzed to enrich UT understanding of SPS and Face to face. Population for this research is all scholarship-students in 37 Regional Office offered scholarship. For comparing learning achievement 
in different SPS types, all GPA are used. Meanwhile, to analyze students' perception, samples were used. A number of six out of 37 Regional Office were chosen as samples purposively to represent Regional Office size (number of students). The Regional Office chosen were Aceh, Batam, Jambi, Pontianak, Bandung, and Palembang. Individual respondents in each Regional Office samples were chosen randomly.

The primary objective of this study is to evaluate SPS implementation based on students' perception and performance. Based on the results, recommendations for the utilization of SPS, especially SPS Plus, will be developed. To achieve the objective, the following research questions are formulated: "How is students' perception toward SPS Plus?", "Have SPS Plus been implemented according to its requirements?" "Is there any significant differences in GPAs for different SPS types?"

This study is significant as the research findings are expected to perfecting UT's student learning services. Results of the study will be useful as input to develop a common strategy to increase the effectiveness of student learning services at UT as well as in other distance education institutions.

Utilizing learning support is not the ultimate goal of being students. It is only a mediation to achieve a higher goal: being a self-directed learner. Self-directed learner, according to Malcolm Knowles (1975:18), is an individual who ".... take the initiative, with or without the help of others, in diagnosing their learning needs, formulating learning goals, identifying human and material resources for learning, choosing and implementing appropriate learning strategies, and evaluating learning outcomes". Self-directed learning can be done individually or in groups, both in the study group and in tutorials. With all learning support provided, it was found out that students often face difficulties to mastering learning materials and achieve target competencies because of they have not yet familiar nor implement self-directed learning (Universitas Terbuka, 2012b). This difficulty due to students still has their traditional pedagogy instead of embracing andragogy. Knowles (1984) mentioned that andragogy was premised on at least five crucial assumptions about the characteristics of adult learners that are different from the assumptions about child learners on which traditional pedagogy is premised. They are:

1) Self-concept: As a person matures his self-concept moves from one of being a dependent personality toward one of being a self-directed human being.

2) Experience: As a person matures he accumulates a growing reservoir of experience that becomes an increasing resource for learning.

3) Readiness to learn. As a person matures his readiness to learn becomes oriented increasingly to the developmental tasks of his social roles.

4) Orientation to learning. As a person mature, his time perspective changes from postponed application of knowledge to immediacy of application, and accordingly his orientation toward learning shifts from one of subject-centeredness to one of problem centeredness.

5) Motivation to learn: As a person matures the motivation to learn is internal.

Furthermore, Thompson (1999) found that successful DE students have these characteristics.

1) Internal locus of control.

Learners at DE system has more internal locus of control than learners in face-to face learning systems. Internal locus of control is beliefs that arise as a result of a person's behavior and undertakings.

2) Independent.

DE students are independent and able to manage learning and succeed in his studies. Nonetheless, this does not mean they are interested to learn independently because they are they still need clear rules and explicitly tell about how they learn. Only with clear guidelines, they will be able to apply the self-learning. 
Distance learners tend to be more intelligent, emotionally stable, trustworthy, compulsive, passive, introverts than on face-to-face learners.

3) Learning styles.

Almost all studies have found no link between sensory learning styles (i.e. auditory, visual, or tactile) with learners' tendency to enroll in DE and tendency to succeed in the system.

However, some research has found that DE learners have fewer concrete learning styles, which shows that they are able to learn different types of learning materials and a variety of activities. DE learners also tend not to need relationships with fellow learners compared to learners face to face. DE initially attractive to those who live far from education institution. Currently, comfort to not have to come to specific place at a particular time is also still one of the reasons people join in distance education. Communication problems often found in educational. Therefore, discussing distance education students should be meant discussing mature students with certain characteristics which could help them success in their study. However, not many distance education students fall into this category. Therefore, students support is needed. One of many efforts to facilitate students is by utilizing technology. Advances in technology open up many possibilities for the communication model of DE. Institutions that implement DE's system can be overcome with advances in communications and information technology. The technology can then be used by students to communicate more intensively with other students and with tutors (Educational Benefits of Online Learning, 1998). Students are also increasingly aware of the learning processes which are then used to expand their learning horizons (Yuan \& Gay, 2006). If the course is designed in an optimal situation, and the performance of tutor in doing tutorial are good, this may affect the level of learner satisfaction (Sinclaire, 2013) and Herman (2012). Furthermore, Stanton (2001) and Olszewski-Kubilius \& Corwith (2011) found that ease intensive communication with the tutors can enhance the learning spirit.

UT utilization of communication technology in the form of online tutorial could benefit students. The difficulty to fit students' need of Face to face is in the perception about Face to face. Mercy (2014) found out that students apathy of Face to face rooted from poor perceptions on Face to face and tutors tend to lecture as in face to face to face teaching. This research used content analysis to analyze students' perceptions of SPS Plus and statistics descriptive to analysis GPA in different types of SPS in scholarships' students.

The population in this study were all students using SPS service, consists of CSR scholarships. Sample drawn from 6 UT Regional Offices: Jambi, Bandung, Palembang, Pontianak, Batam, and Aceh; presenting of students using SPS Plus with a GPA of high, medium, and low. Data to determine students' perceptions of service were taken from questionnaires and interviews with students, Coordinator of Student Support Service, and Head of Regional Office.

To analyze whether SPS Plus services can increase the value of the GPA, these secondary data were used.

a. GPAs from semesters 1 through 4 for scholarships student in SPS Plus registered at 2012.2

b. GPAs from semester 1 and 2 for scholarships student SPS Plus registered at 2013.2

c. GPAs from semesters 1 through 4 for students with non-Face to face SPS services

\section{Scholarship-Students' GPA}

All 4,764 GPAs of 706 scholarship-students from 6 Regional Offices were used to examine differences between GPA SPS types (Figure 1). The T-test between SPS types is conducted to compare students' learning achievement based on Face to face, SPS Plus, SPS Semi, and SPS Non-Face to face. The T-test were also administered between semesters to analysis the differences between students' learning achievement in different semesters. While comparison between SPS type could enlighten us on the comparison between semester could show how course load affect GPAs. All 706 scholarship-students firts registered 2012.2-2013.2 semester is registered in six study programs from three faculties, namely 
Faculty of Natural Science \& Mathematics (Agricultural Extension, Environment, Statistics), Faculty of Social \& Political Sciences (Communication Science), and Faculty of Economics (Management, Accountancy).

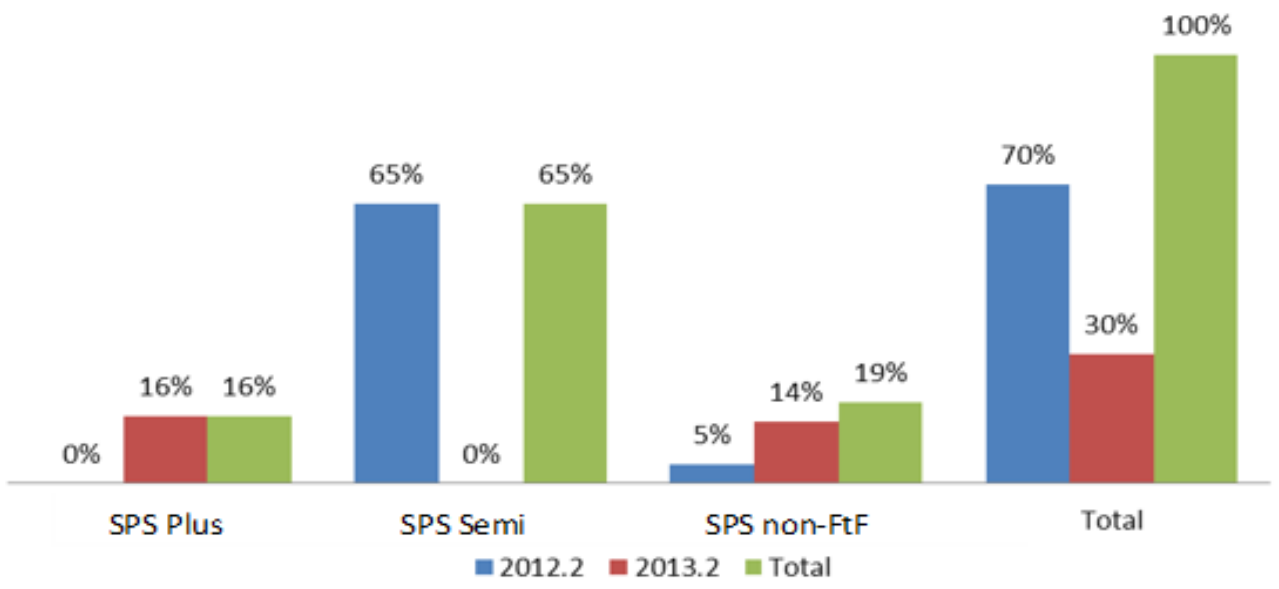

Figure 1. Distribution of scholarship-students based on SPS types \& semester of first registration $(\mathrm{N}=706)$.

Using T-test, combinations of scholarship-students in the three types of SPS in the first, second, third, and fourth semesters of study are examined. Meanwhile, results for the t-test are presented in Table 1. Seven from eight combination of SPS Types and semesters show statistically significant differences between the means. Means of GPA of scholarship-students in SPS Plus in every semester and in total length of study proven to be higher than those in other types of SPS. Meanwhile, only in semester 2, means of GPAs of scholarship-students in SPS Plus same with those in SPS Semi.

Table 1. Number of observation, mean, and variance in each SPS types and semesters.

\begin{tabular}{ccccc}
\hline \multirow{2}{*}{ Semester } & Statistics & SPS Plus & SPS Semi & $\begin{array}{c}\text { SPS Non- } \\
\text { Face-to-face Tutorial }\end{array}$ \\
& Observation & 111 & 461 & 134 \\
1 & Mean & 2,77 & 2,46 & 2,12 \\
& Variance & 0,29 & 0,19 & 0,35 \\
& Observation & 220 & 454 & 113 \\
2 & Mean & 2,44 & 2,39 & 2,07 \\
& Variance & 0,49 & 0,22 & 0,50 \\
& Observation & 407 & - & 50 \\
3 & Mean & 2,68 & - & 1,79 \\
& Variance & 0,41 & - & 0,57 \\
& Observation & 384 & - & 48 \\
4 & Mean & 2,80 & - & 1,83 \\
& Variance & 0,52 & - & 0,62 \\
& Observation & 1122 & 915 & 345 \\
& Mean & 2,68 & 2,43 & 2,01 \\
& Variance & 0,47 & 0,20 & 0,48 \\
\hline
\end{tabular}

Therefore, UT has to take certain measures to overcome this barrier such as providing intensive training to prepare students to engage in DE. In addition, UT should motivate students' to self-learning by presenting success stories from alumni. 
Table 2. Results of t-test in different combination in SPS programs (hypothesized mean difference $=0, \alpha 0.05$ ).

\begin{tabular}{|c|c|c|c|c|}
\hline Semester & Statistics & SPS Plus \& SPS Semi & $\begin{array}{c}\text { Type of SPS } \\
\text { SPS Plus \& } \\
\text { SPS Non-Face to face }\end{array}$ & $\begin{array}{l}\text { SPS Semi \& SPS } \\
\text { Non-Face to face }\end{array}$ \\
\hline \multirow{5}{*}{1} & df & 146 & 241 & 176 \\
\hline & t Stat & 5.72 & 9.08 & 6.24 \\
\hline & $\mathrm{P}(\mathrm{T}<=\mathrm{t})$ one-tail & 2.94E-08 & $1.96 \mathrm{E}-17$ & $1.59 \mathrm{E}-09$ \\
\hline & \multirow{2}{*}{$\begin{array}{l}\text { t Critical one-tail } \\
\text { Decision }\end{array}$} & 1.66 & 1.65 & 1.65 \\
\hline & & Reject null hypotheses & Reject null hypotheses & Reject null hypotheses \\
\hline \multirow{5}{*}{2} & df & 319 & 224 & 138 \\
\hline & t Stat & 0.85 & 4.51 & 4.61 \\
\hline & $\mathrm{P}(\mathrm{T}<=\mathrm{t})$ one-tail & 0.20 & $5.23 \mathrm{E}-06$ & $4.46 \mathrm{E}-06$ \\
\hline & t Critical one-tail & 1.65 & 1.65 & 1.66 \\
\hline & Decision & Accept null hypotheses & Reject null hypotheses & Reject null hypotheses \\
\hline \multirow{4}{*}{3} & $\begin{array}{c}\text { df } \\
\text { t Stat }\end{array}$ & & $\begin{array}{c}58 \\
7.98\end{array}$ & \\
\hline & $\mathrm{P}(\mathrm{T}<=\mathrm{t})$ one-tail & & $3.28 \mathrm{E}-11$ & \\
\hline & t Critical one-tail & & 1.67 & \\
\hline & Decision & & Reject null hypotheses & \\
\hline \multirow{5}{*}{4} & df & & 57 & \\
\hline & t Stat & & 8.14 & \\
\hline & $\mathrm{P}(\mathrm{T}<=\mathrm{t})$ one-tail & & $2.03 \mathrm{E}-11$ & \\
\hline & t Critical one-tail & & 1.67 & \\
\hline & Decision & & Reject null hypotheses & \\
\hline \multirow{5}{*}{$\begin{array}{l}\text { Whole } \\
\text { Semester }\end{array}$} & df & 1957 & 565 & 459 \\
\hline & t Stat & 10.16 & 15.73 & 10.24 \\
\hline & $\mathrm{P}(\mathrm{T}<=\mathrm{t})$ one-tail & $5.95 \mathrm{E}-24$ & $8.76 \mathrm{E}-47$ & $1.30 \mathrm{E}-22$ \\
\hline & t Critical one-tail & 1.65 & 1.65 & 1.65 \\
\hline & Decision & & & \\
\hline
\end{tabular}

\section{Scholarship-Students Perception on the Face to Face Tutorial Implementation}

To analyze the students' perception on the implementation of Face to face in SPS Program, a number of 143 students served as samples. The students were from six Regional Offices chosen, Aceh, Batam, Bandung, Palembang, Pontianak, and Jambi. Most of the respondents were female (75,5\%). Based on study programs, majority of the students were from Urban and Regional Planning Study Program (Figure 2).

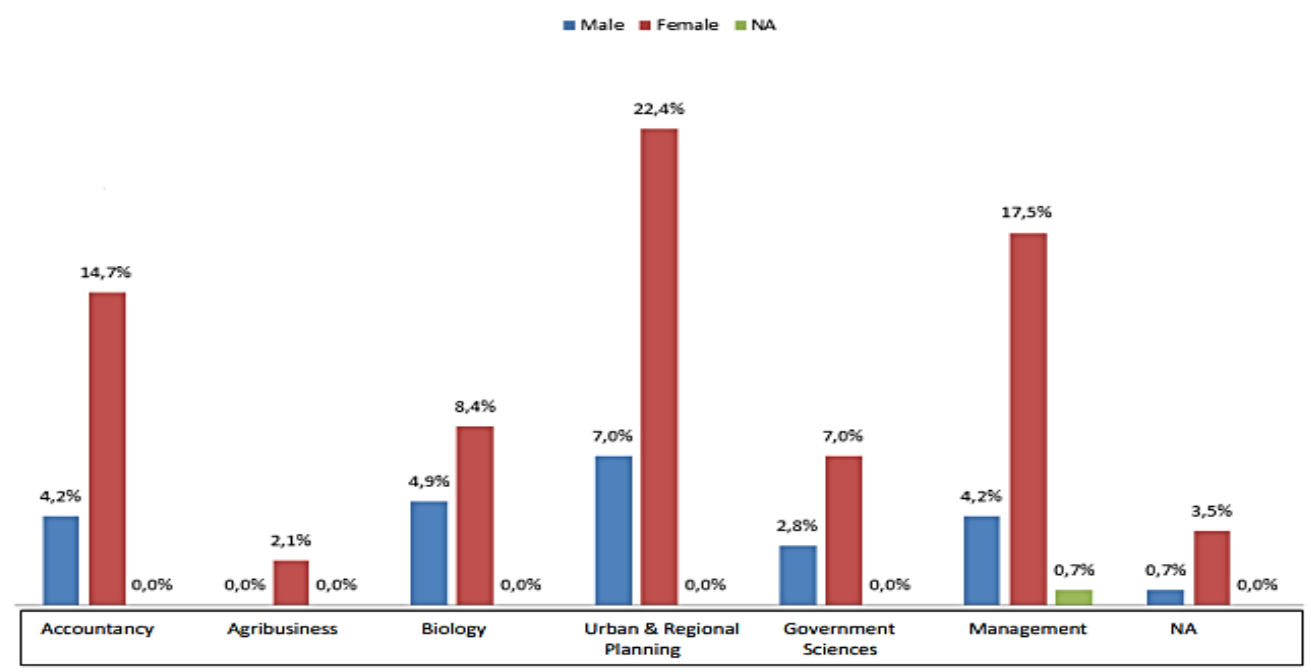

Figure 2. Respondents' distibution based on study program. 


\section{Scholarship-Students' GPA}

The difference between the various types of SPS lies in the difference in the number of face to face. Therefore, based on the results, it can be concluded that the greater number of courses completed with the face to face, the higher learning outcomes. Findings that face to face still affect students' GPAs reflects that scholarship-students have not yet had a characteristic of andragogy as mentioned by Knowles (1984) such as self-concept which is reflected in moving from one of being a dependent personality toward one of being a self-directed human being. In other word, fresh graduate students have not ready for directed-learning. This finding also contradicts Thompson (1999) belief that successful DE students are more introverts than on face-to-face learners. While Tait (2003) said that students look for the flexibility that ODL offers, especially freedom from time and place that is restricted by convention-al part-time study, and they do need student support.

\section{Scholarship-Students Perception on the Face to Face Implementation}

As stated in UT Catalog 2012, during Face to face students have to actively involved in the discussions. In order to be able to do that, students have to read related modules first. Therefore, having modules is a must for every student. In terms of modules delivery, all students stated that they have received all modues prior to the first Face to face session. In the eprocedure of delivering modules, UT has tergetted that students should receive the modules at least two weeks before the first face to face session. However, only $46 \%$ respondents received their modules on time. Other respondents receive the modules one week before the first session of face to face. This situation could be rooted from the unpredictable number of new students since students tend to register right by the end of registration day. Hence, time to prepare the delivery such as preparing and printing the modules is limited. In addition, sometimes, it is difficult to predict time require to deliver the modules to students. Based on these findings, UT has to be more strict in the registration process. It is also be necessary to provide more time in delivering the modules and at the same time increase monitoring and control of the delivery.

Meanwhile, information about face to face were provided in time. Majority (66\%) respondents mentioned that they received information on face to face tutorial schedule two week prior to the first session of Face to face. Students need the schedule in order to prepare their time and materials for the Face to face. In addition, students also need the information so they could know the location of Face to face. Majority of respondents $(92,3 \%)$ mentioned that face to face could be conducted at Regional offices. Meanwhile, $80 \%$ respondents beliefed that Face to face have to be conducted at Regional office. However, face to face should also be conducted everywhere. Choices of location for face to face to some extend reflects scattered domiciles of the respondents. UT regulation on Face to face allows Regional Office to concduct Face to face everywhere.

In terms of tutors, respondents' spoke highly of them because the tutors come from relevant study program and able to conduct the Face to face. Respondents' perception on the ability of tutors in managing Face to face is not inline with UT regulation of role of tutors in face to face. UT states that tutors have to take roles as facilitators not lecturers. Findings that reflects non-confirmity in the role of tutors has to be addressed by UT by providing training for tutors and administer more intensive monitoring and evaluation.

During Face to face, several topics were discussed. Majority of respondents (98\%) stated that they only discuss topics covered in modules while $84 \%$ respondents stated that they also discussed topics outside for the moudles. This rather odd number could occur because the respondents have to express their perceptions on several courses. It could happen that there are differences in choosing topics based on courses which are not analyzed in this paper. Other than discussions, respondents should also engage assignments. A number of $72 \%$ respondents carried out their assignments both in group 
and individually while only $22 \%$ and $6 \%$ respondents carried out the assignments individually and in group. Almost all respondents (98\%) doing their assignments during their Face to face sessions and this is inline eith UT regulation.

\section{Conclusion}

SPS Plus has proven to be effective in facilitating students learning process as shown in the highest GPAs between three types of SPS. In all combination of SPS types and semesters, SPS Plus always has statistically significant highest mean of the GPA. These findings, while satisfying students' need to achieve high GPA, could cause problem in the efforts to promote students ability in self-directed learning. Therefore, UT needs to limit the implemantation of SPS Plus. SPS Plus could be implemented in the firts four semesters but eventually SPS Plus should be replaced by SPS Semi or SPS Non-Face to face.

\section{References}

CalPly Edu. (1998). Educational Benefits of Online Learning. http://blackboardsupport.calpoly.edu/ content/faculty/handouts/Ben_Online.pdf. pp. 1-6. Retrieved 29 March 2013.

Herman. (2012). Face-to-face Tutorials in ODE and Student Satisfaction in Indonesia. Asian Journal of Distance Education, $10(2), 4$-13.

Knowles, M. S. et al. (1984). Andragogy in Action. Applying Modern Principles of Adult Education. San Francisco: Jossey Bass. A Collection of Chapters Examining Different Aspects of Knowles' Formulation.

Mercy, K. (2014). Weekend School Face- to-Face Tutorials Apathy in ODL. A Case of Zou Midlands Region: Zimbabwe. Academic Journal of Interdisciplinary Studies, 3(6).

Olszewski-Kubilius, P. \& Corwith, S. (2011). Distance Education: Where It Started and Where It Stands for Gifted Children and Their Educators. Gifted Child Today. 4(3), 16-24.

Stanton, S. (2001). Going the Distance; Developing Shared Web-based Learning Programmes. Occupational Therapy International, 8(2), 96-106.

Thompson, M. (1999). Distance Learners in Higher Education. http://web.worldbank.org/archive/ website00236B/WEB/KN_02.HTM. Retrieved June 15, 2015.

Tait, A. (2003). Reflections on Student Support in Open and Distance Learning. International Review of Research in Open and Distance Learning, 4(1), http://oro.open.ac.uk/1017/1/604.pdf. Retrieved June 15, 2015.

Universitas, T. (2012a). Sistem Jaminan Kualitas Universitas Terbuka (UT Quality Assurance System). Tangerang Selatan: Universitas Terbuka.

Universitas T. (2012b). Panduan Paket Arahan Prodi NonPendas (Guide to Directed Packages for Non-Education Study Programs). Tangerang Selatan: Universitas Terbuka.

Universitas T. (2014). Rencana Strategis \& Rencana Operasional UT 2010-2021. Versi Penyempurnaan (UT 2010-20121 UT Strategic \& Operational Planning. Revised Edition). Tangerang Selatan: Universitas Terbuka.

Universitas T. (2014). Laporan Kerja Tahunan Rektor Universitas Terbuka 2013 (2013 Annual Report of Universitas Terbuka's Rector). Tangerang Selatan: Universitas Terbuka.

Universitas T. (2016). Katalog UT 2016 (UT Catalog 2016). Tangerang Selatan: Universitas Terbuka.

Yuan, Y. C. \& Gay, G. (2006). Homophily of Network Ties and Bonding and Bridging Social Capital in Computer-Mediated Distributed Teams. Journal of Computer-Mediated Communication. 11(4): 1062. doi:10.1111/j.1083-6101.2006.00308.x 